\title{
GÖÇERLERDE TOPLUMSAL YAPI VE ÇÖKÜŞ ÜZERINE KURAMSAL BİR DEĞERLENDİRME
}

\author{
A Theoretical Research on Social Structure and Collapse Within Nomads
}

\section{Mehmet YAZICI ${ }^{1}$}

ÖZET

Sosyolojik açıdan toplumsal çöküş nitelemesi, genelde ömrünü tamamlamış toplumsal yapılar için kullanılmaktadır. Toplumsal yapının diğer aşamalarına gösterilen ilgiyle karşılaştırıldığında toplumsal çöküş çalışmalarının, ihmal edildiği görülmektedir. Tarih boyunca, geçirdiği değişim süreci çöküşle sonuçlanmış pek çok toplumsal yapı örneğiyle karşılaşılmaktadır. Bu çöküşlerin "çatışmalı" ve "çatışmasız" olarak iki farklı biçimde meydana geldiği tespit edilmiştir. Çöküşle sonuçlanan toplumsal yapılardan biri Türkiye’nin Doğu Anadolu Bölgesi’ndeki göçer toplumsal yapısıdır. Bu çalışmada, göçer toplum yapısının sosyal ilişki ağı, çöküşü ve nedenleri kuramsal bir yaklaşımla ele alınıp incelenmektedir. Çalışmada, bir toplumsal yapıda yaşayan bireylerin dış faktörlerden etkilenmesinin, o yapıya ait değerlerin anlamını yitirmeye başlamasına ve zamanla yapının çökmesine neden olduğu tezi ileri sürülmüştür. Çalışmada varılan sonuçların, göçer toplum yapısıyla birlikte, toplumsal çöküş olgusunun da daha iyi anlaşılmasına ve bu konudaki literatürün geliştirilmesine katkıda bulunacağı düşünülmektedir.

Anahtar Kelimeler: Göçerler, toplumsal çöküş, coğrafi potansiyel, toplumsal yapı

\section{ABSTRACT}

Conceptualisation of social collapse from a sociological perspective is generally used for social structures which have completed their life. Social collapse resarches is neglected in sociology as compared to other periods of social structure. Throughout the history, it can be faced with many societies which experienced social collapse. It was found that those collapses occurs in two types as "conflictual" and "conflictless". One of those societies that experienced social collapse is nomadic social structure in the East of Turkey. In this study, the collapse of nomadic social structure was handled and investigated in a theoretical perspective. In the study, the hypothesis of "individuals who are living in a social structure are affected by outer factors. This situation causes the values which are belonged to the society begin to lose meaning. During the process of testing the hypothesis in a theoretical perspective, datas which are collected through literature review, observations and interview in the field were used. It is thought that the results of this study will contribute to understand social collapse phenomenon better and develope literature for this subject.

Key Words: Nomads, social collapse, geographic potential, social structure

\section{GİRIŞ}

Her toplumsal yapının; kuruluşu, öğeleri, aşamaları ve çöküşle son bulan bir ömrü vardır. Toplumsal yapıların yaşadığı değişimin yönü, hızı ve değişim üzerinde etkili olan faktörlerin nitelikleri, yapının çöküşünde de belirleyici bir etkiye sahiptirler. Bundan dolayı, konuyla ilgili çalışmalarda değişim ile çöküş arasında bir neden-sonuç ilişkisi kurulmaktadır. Ancak bu ilişkilendirme, toplumsal değişimeye gösterilen ilgiyle karşılaştırıldığında, çöküş konusunun ihmal edildiği görülmektedir.

Toplumsal çöküş, sosyolojik açıdan ömrünü tamamlamış ve tarihe mal olmuş toplumsal yapıların son aşaması olarak tanımlanabilir. Bu tanımdan hareketle, toplumsal çöküşün; tarihte yaşamış toplum sayısı kadar tekrarlanmış sosyolojik bir gerçeklik olduğu da söylenebilir. Toplumsal yapıların statik durumu kadar, yaşadıkları değişimler, çöküşler ve bunların sonuçları; sosyoloji, tarih, -özellikle de- tarih felsefesi, siyaset bilimi başta olmak üzere, farklı sosyal bilimler tarafından çeşitli yönleriyle ele alınmış ve bu konuda bir literatür meydana gelmiştir. Ancak,

\footnotetext{
${ }^{1}$ Yrd. Doç. Dr., Bingöl Üniversitesi Öğretim Üyesi BİNGÖL Mail: yazici44@gmail.com
} 


\section{F.Ü. Sosyal Bilimler Dergisi 2016-26/1}

toplumsal çöküş kavramı ve bu kavramın tanımladığı sosyolojik durumun nedenlerinin ve sonuçlarının henüz tam olarak açıklığa kavuşturulmadığı ifade edilebilir. Toplumsal çöküşle ilgili tartışmalar; değişimin çöküşle ilişkisinin ne olduğu, değişimin ve çöküşün belirleyici nedenlerinin iç ya da dış faktörlerden hangisiyle açıklanabileceği, toplumsal değişim ve çöküş durumlarının bozulma mı yoksa yenilenme mi olduğu veya değişim ve çöküşün olumlu ya da olumsuz olarak değerlendirmesinin çeşitli faktörler tarafından nasıl etkilendiği, toplumsal yapının çözülme ve çöküş süreci durdurulabilir mi? gibi sorulara verilen farklı cevaplar etrafında sürdürülmektedir.

Konuyla ilgili tartışmalarda iki nokta ön plana çıkmaktadır. Birincisi, yapılan çözümlemelerde yapıların nitelik ve nicelikleriyle ilgili farklılıkların göz ardı edilmesidir. Bu durumu Kongar (2012a: 445), şu ifadelerle dile getirmektedir: "Kanımca, bugünkü toplumbilimcileri çok büyük bir yaklaşım yanlışı içindedirler: Büyük boy çözümlemeler için hazırlanmış modelleri orta boy ve küçük boy irdelemeler için de kullanmaktadırlar. Oysa, zaman boyutu değiştiği zaman, olayların niteliği de, çözümlemelerin teknik ve yöntemleri de farklı olmaktadır." İkincisi ise; sosyal-kültürel değişimin, toplumsal yapının çözülmesinin ve çöküşünün nedeni olarak değerlendirilmesidir. Örneğin; "Platon, bütün toplumsal değişimin bozulma, çürüme, yahut soysuzlaşmadan ibaret olduğu görüşündedir" (Okumuş, 2007: 212). Ercan (2011:17)'ın tespitine göre; Osmanlı siyasasını güçlü ve tüm toplum üzerinde belirleyici olarak kabul eden araştırmacılar da toplumsal değişmenin olmadığı görüşünü kabul etmektedirler. $\mathrm{Bu}$ araştırmacılar, yaptıkları çalışmalarda, toplumda gözlemlenen farklılıkları, "değişme" değil "bozulma" olarak görmektedirler. Örneğin; Barkan, çalışmalarında değişimi "soysuzlaşma" olarak nitelemiştir. Kıvılcımlı için, kurum ve ilişkilerdeki farklılaşma "çürüme"; Berkes için ise "bozulma"dır. Bu örnekler, sosyal-kültürel değişmeye kuşkuyla yaklaşmanın, hatta toplumsal değişmeyi, toplumsal yaşamda meydana gelen olumsuzlukların ve bozulmaların nedeni olarak görmenin, bir kişi, bir toplum veya bir dönemle sınırlı olmadığını göstermektedir.

Araştırmada, toplumsal çöküşle sosyolojik ömrünü tamamlamış bir toplumsal yapı örneği olarak, göçer toplum yapısı ele alınmaktadır. Bu yapıyla ilgili çözümlemeler; toplumsal yapı, değişim, çözülme ve çöküş kavramları bağlamında yapılmaktadır.

\section{ARAŞTIRMANIN YÖNTEMI}

Türkiye'nin Doğu Anadolu Bölgesi, hayvancılık yapmak için gerekli coğrafi ve biyolojik potansiyele sahiptir. Bölgenin bu potansiyelinden yararlanmak amaciyla burada hayvancılık yaparak geçinen topluluklar yaşamaktadır. Anadolu'nun, insanlık tarihi içerisindeki yeri göz önüne alındığında, bu toplulukların tarihinin, insanlık tarihiyle yaşıt olduğu ileri sürülebilir.

Çalışmanın temel amacı, hayvancılığı bir faaliyet biçimi olarak seçen ve toplumsal örgütlenmesini buna göre şekillendiren bölgedeki göçer toplulukların nasıl bir toplumsal yapı meydana getirdiğini, bu uzun ömürlü yapının geçen yüzyılın son çeyreğinde neden ve nasıl çöktügünü açıklamaktır. Bir diğer amacı ise, Doğu Anadolu Bölgesi'ndeki göçerlerin çöken toplumsal yapı örneğinden hareketle, toplumsal çöküş olgusunun daha iyi anlaşılmasına ve bu konudaki literatürün geliştirilmesine katkıda bulunmaktır.

Literatürde çöküş kavramı, genellikle, medeniyet/uygarlık kuramcıları tarafindan tarih sahnesinden çekilmiş uygarlıkların veya kültürlerin ölümü için kullanılmaktadır. Spengler (1997) ve Toynbee (1978), bu yöndeki çalışmalarıyla ön plana çıkmış kuramcılardır. Sorokin (1972) ise, başta bu iki kuramcının çalışmaları olmak üzere, makro düzeyde yapılan toplumsal çöküş değerlendirmelerini eleştirmektedir.

Sorokin (1972: 256-258), Spengler'in ve Toynbee'nin sınıflamalarını, uygarlık veya kültür sistemleri sınıflandırılması olmaktan ziyade, toplumsal sistem (örgütlenmiş/toplumsal gruplar) sınıflamaları olarak nitelemektedir. Ona göre, bu yazarların inceledikleri uygarlık ya da kültür tipi bütünlenmiş tek bir sistem değildir. Bütünlenmiş ya da birleşmiş olmadıklarına göre çözülmeleri de söz konusu olamaz. Ayrıca, çöktüğü/öldüğ̈̈ ilan edilen uygarlık veya kültürlerin belli bir takım özellikleri yok olmuşsa da, başka bir takım özellikleri ise varlığını sürdürmektedir. Örneğin, "sona 
erdiği” ileri sürülen Yunan-Roma uygarlığının edebiyatı, felsefesi, ahlâk sistemlerinin çoğunluğu, güzel sanatları, mimari biçimleri, matematik ve bilim bulguları, siyasal ve ekonomik örgütlenme biçimleri, iç hukuk düzenlemeleri ve daha birçok gelenek ve görenekleri ... "Bunlar ve YunanRoma uygarlığının daha birçok öteki kültürel değerleri hâlâ uygarlık, kültür ve kurumlarımızda, zihniyetimiz, davranış ve ilişkilerimizde taklit edilmekte, uygulanmakta ve onların yapısına yerleşmiş bulunmaktadır" (Sorokin, 1972: 260). Aynı durum, Mısır'dan Osmanlı’ya değin, "ölü” olduğu ileri sürülen öteki on beş uygarlı için de geçerlidir. Oysa, "toplumsal grupların ömürsüreleri gerçekten sonludur. Söz konusu yazarlar ise, uygarlıksal sistemleri toplumsal gruplarla karıştırarak, toplumsal grupların sınırlı yaşam-sürelerini kültürel ve uygarlıksal sistemlere yakıştırmışlardır (izafe etmişlerdir). Fakat burada da, toplumsal grupların yaşam-süresi üzerine hemen hiçbir çözümleme yapmamışlardır” (Sorokin, 1972: 262).

$\mathrm{Bu}$ çalışmada, Sorokin'in eleştirileri göz önünde bulundurularak, bütünleşmiş ve zamanla çökmüş bir toplumsal grup/yapı örneği olarak göçerler ele alınmaktadır. Bu yapının çözümlemelerinden hareketle, toplumsal çöküşün mikro düzeyde bir değerlendirmesi yapılmaktadır.

Göçer topluluklar, sosyologlar tarafindan yapılan toplum tipi kategorileştirmelerde uygarlık/ yazı öncesi (Sorokin, 1972: 260) topluluk örneğini oluşturmaktadır. Bu toplulukların en önemli özelliği, insan dışı tabiatla kurdukları ilişkiler bağlamında bir toplumsal yapı meydana getirmiş olmalarıdır. İnsanoğlunun, toplumsal ilişkiler ve insan dışı tabiatla ilişkiler alanında kaydettiği kültürel ilerlemelere bu toplulukların katkısının olduğu kabul edilmektedir (Toynbee, 1978: 76). Benzer çalışmalar, hem bu nitelikteki katkıların, hem de modern toplumların geçirdikleri aşamaların daha iyi anlaşılmasını sağlayacaktır. Sorokin (1972: 260)'e göre, “yazı öncesi, göçer, çoban ve tarımcı kabilelerin birçok kültür değerinin; ulaştırma, teknoloji, ekonomi yöntemleri, beğeni, sanat kalıpları, büyü ve din inanışları, gelenek ve görenek gibi etkenleri kapsayarak kültürümüzde geniş çapta yaşadığı ve hatta işlediği bile güvenle ileri sürülebilir.” Bu bağlamda, çalışmanın, göçer toplulukların, insanlık tarihiyle yaşıt toplumsal yapılarının esasları ve toplumsal çöküşleriyle ilgili sosyolojik analizlerin, genel olarak toplumsal yapıların çöküş nedenlerinin kavranmasına ve çöküş sonrası toplumsal eğilimlerin önceden saptanmasına katkısı olacaktır.

Konuyla ilgili çalışmalarda, genellikle toplumsal yapılar için sosyal-kültürel değişimin önemi, anlamı ve toplumsal çöküşle ilişkisi, çöküşün nedenleri, çöküş süreci, çatışma ve çözülmenin çöküşle son bulmasının önlenip önlenemeyeceği konuları üzerinde durulduğu görülmektedir. Ancak, toplumsal yapıların yaşadığı "çöküş" üzerinde yeterince durulmadı̆̆ı, sosyolojik analizlerin yapılmadığ1 ve bu noktanın ihmal edildiği anlaşılmaktadır. Oysa, tarihte yaşanmış toplumsal çöküş örnekleri incelendiğinde, tüm toplumsal çöküşlerin aynı olmadığı, çöküş örneklerinin çatışmalı ve çatışmasız çöküşler olarak iki farklı grupta sınıflandırılabileceği görülmektedir.

İki toplumsal çöküş biçimi arasındaki farklar aşağıdaki gibi maddeleştirilebilir:

\begin{tabular}{|c|c|}
\hline Çatışmalı Çöken Toplumsal Yapılar & Çatışmasız Çöken Toplumsal Yapılar \\
\hline $\begin{array}{l}\text {-Toplumun üyelerinin büyük çoğunluğu için; üretim araçlarına, } \\
\text { üretim biçimine ve sosyal ilişki kalıplarına yüklenen "anlam" } \\
\text { geçerliliğini yitirmiştir. } \\
\text {-İçinde yaşanılan mekan, üyeler için önemini korumaktadır. } \\
\text {-Değişimden yana olan toplum üyeleri, toplumsal yapının sosyal } \\
\text { ilişki kalıplarını, üretim araçlarını ve mekanı dönüştürmek } \\
\text { istemektedirler. } \\
\text {-Değişim taleplerini dış faktörler belirlemektedir. Yapıya } \\
\text { eklenen yeni öğeler, mevcut öğeleri değişmeye ve dönüşmeye } \\
\text { zorlamaktadır. } \\
\text {-Çöküş sürecinde; çözülme, çatışma ve anomi yaşanır. } \\
\text {-Yapının, değişimi talep eden üyeleri ve grupları ile mevcudu } \\
\text { korumak isteyen bireyler ve gruplar arasında çatışmalar yaşanır. } \\
\text { Değiş̧imi talep edenlerin yeni bir formla, yeni bir yapı kurma } \\
\text { çabası vardır. }\end{array}$ & $\begin{array}{l}\text {-Toplumun üyelerinin büyük çoğunluğu için, hem üretim araçlarına } \\
\text { ve üretim biçimine, hem de sosyal ilişki kalıplarına yüklenen } \\
\text { "anlam”, geçerliliğini yitirmiştir. } \\
\text {-İçinde yaşanılan mekan, üyeler için önemini kaybetmiştir. } \\
\text {-Değişimden yana olan toplum üyeleri, toplumsal yapının sosyal } \\
\text { ilişki kalıplarını, üretim araçlarını ve mekanı dönüştürmek yerine, } \\
\text { terk etmeyi tercih etmektedirler. } \\
\text {-Değişim taleplerini dış faktörler belirlemektedir. Yapıya yeni } \\
\text { öğeler eklenmez. Alternatif bir dış yapı, mevcut yapının üyeleri } \\
\text { için cazibe merkezi olma niteliği kazanır. } \\
\text {-Çöküş sürecinde çatışma ve anomi yaşanmaz. } \\
\text {-Yapıyı terk eden üyeleri ile mevcudu korumak isteyen bireyler ve } \\
\text { gruplar arasında çatışma yaşanmamaktadır. Değişimi talep } \\
\text { edenlerin yeni bir formla, yeni bir yapı kurma çabası da yoktur. } \\
\text { Yeniden yapılaşma çabası en zayıf düzeyde gözlenmektedir. }\end{array}$ \\
\hline
\end{tabular}




\section{F.Ü. Sosyal Bilimler Dergisi 2016-26/1}

Çatışmasız çöken toplumsal yapılara, göçer toplum yapıların yanında, tarihin belli dönemlerinde kültür ve ticaret merkezi olmuş; ancak daha sonra bu özelliklerini yitirmiş, hatta tamamen terk edilmiş şehirler de örnek olarak verilebilir.

Çalışmayı önemi kılan özelliklerden biri de, toplumsal çöküşlerin, çatışmalı toplumsal çöküşler ve çatışmasız toplumsal çöküşler şeklinde gerçekleştiğini saptadıktan sonra, çatışmasız toplumsal çöküşü göçer topluluklar örneği bağlamında tahlil etmesidir.

Literatür taraması sonucunda elde edilen verilerin değerlendirilmesinde; bölgedeki geleneksel göçer toplum yapısının önce toplumsal çözülme, daha sonra da çöküş yaşadığı sonucuna varılmaktadır. Bu yapının çöküşü sürecinde, çatışma ve anomi yaşanmadığı tespitinden hareketle, meydana gelen çöküşün "çatışmasız çöküş örneği" olduğu ileri sürülmektedir.

\section{KAVRAMSAL ÇERÇEVE: TOPLUMSAL YAPI VE ÇÖKÜŞ}

Göçerler, basit bir örgütsel yapıya, fakat karmaşık sosyal ilişkiler ağına sahiptirler. Çalışmanın, bu yapının çatışmasız çöküşle son bulduğu varsayımı, beraberinde bu çöküş temelde ne ile açıklanabilir? sorusunu cevaplamayı gerektirmektedir. Bu sorunun cevabı, sosyolojinin kadim paradokslarından biri olan "yapının ikili karakteri”ni gündeme getirmektedir. Sosyal gerçekliğin bu iki farklı boyutundan hangisinin belirleyici olduğu tartışması henüz bir sonuca bağlanmış değildir. Bazı sosyologlar ve sosyal antropologlar bireyselci yaklaşımı benimserken, bazıları kolektivist yaklaşımı benimsemektedir. Bazıları da bu iki boyutu bağdaştıran görüşler ileri sürmektedirler (Bkz. Eriksen, 2009: 123-126). Akşit (2012: 77)'in de belirttiği gibi, "kuramların açıklamaya çalıştığı gerçekliğin ve odaklandığı düzeyin makro veya mikro düzeyde olması veya bu iki düzey arasındaki bağlantıları dikkate alıp almaması çok önemli tercihlerdir. Benzer şekilde yapıya odaklanıp; kişi, kişiler arası etkileşim ve grup düzeyindeki failleri dikkate almamak veya tam tersine kişiler arası etkileşimi ve failleri dikkate alıp, yapı düzeyindeki süreçleri dikkate almamak veya bunlar arasındaki diyalektik süreçleri dikkate almak kuramsallaştırmada çok önemlidir. Son zamanlardaki sosyolojik kuramlaştırma denemeleri, mikro ve makro düzeyleri, fail ve yap1 diyalektiğini dikkate alarak yapılanlardır."

Failler/bireyler, kendilerinden önce "yapılaşmış" ve belli oranda değişerek kuşaktan kuşağa aktarılmış bir toplumun içine doğarlar. Bireylerin, içinde etkinlikte ve sosyal etkileşimde bulundukları toplum, "insanlar arasındaki toplam ilişkiler ağıdır. Bu durumda toplumu meydana getiren, elemanlar arasındaki ilişkiler değil, insanlar arasındaki ilişkilerdir" (Toynbee, 1978: 45). Toynbee (1978: 169)'ye göre, bu özellikleriyle “toplumlar, anlaşılabilir inceleme alanlarıdır; nesnel terimlerle söylendiğinde, toplumlar, çok sayıda insanın birey olarak etkinlik gösterdiği değişik alanların ortak zeminidir; bir toplumun tarihi ve zaman içindeki uzamını, oradaki bireylerin canlı güçler olan enerjileri belirler". Aynı zamanda, toplumsal yaşamı mümkün ve anlamlı kılan temel dinamik, yine bireylerin bu enerjileridir. "Her şeyden önce, toplumsal yaşam, eylem veya etkileşimden ibarettir. İnsanlar etkileşime son verselerdi eğer, toplum varlığını devam ettiremezdi" (Eriksen, 2009: 73). Bundan dolayı, bir toplumsal yapıyı ve serüvenini anlamaya, "her ne kadar yapısalcı yaklaşımlar reddetse de bireylerden, aktörlerden veya faillerden başlamak durumundayız" (Akşit, 2012: 77). Çünkü, "toplumsal ilişkinin ortaya çıkışını ve inşa edilişini ele almalıyız. Toplumsal durumlara göre değişen karş1lkklı etkileşim (situated activitiy), anlaşma ve anlamlandırma süreçleri, toplumsal ilişkinin inşa edildiği, yeniden üretildiği, dönüştürüldüğü veya sona erdirildiği alandır” (Akşit, 2012: 77).

Toplumsal hayat, birbirleriyle etkileşim içinde olan farklı bileşenlerin sonucu olarak ortaya çıkar. Sorokin, sosyo-kültürel sistemin bileşenlerini "anlam" üzerinden temellendirmektedir. Ona göre, sosyo-kültürel sistemlerin yapısını belirleyen üç bileşen vardır. Bunlar: a) maddî olmayan, zaman ve mekânsız anlamlar; b) anlamları maddîleştiren (maddî) araçlar; c) maddî araçların yardımıyla bu anlamları işler hâle getiren insan unsuru" (Erkilet, 2013: 17) biçiminde sıralanabilir.

Anlamı merkeze alan yaklaşımın öncüsü Weber'dir. 'M.Weber'in anlamcı sosyolojisinin temel yaklaşımı, sosyal eylemi yönlendiren kültürel motifleri (değerler, normlar, inançlar, 
kurumlar, kolektiflikler vb.) anlamaktır. Bu da sosyal eylemi ortaya koyan aktörlerin kendilerine özgü olan anlamlandırma sistemlerini kavramaktan geçer" (Bal, 1997: 34). "Toplumbilimciler, sosyo-kültürel fenomene 'sosyo-kültürel olma' niteliğini kazandıran anlamlar üzerinde odaklaşmak durumundadır. Fiziksel özellikleri aynı olan iki davranış, kendilerine atfedilen anlamdan dolayı, çok farklı toplumsal davranışlar haline gelebiliyorsa, bu anlam, onların aslî niteliklerine empoze edilerek onu geri plâna itebiliyorsa, bu durum, anlam bileşeninin, toplumbiliminin temel inceleme konusu olduğunu gösterir" (Erkilet, 2013: 19-20)

Çalışmanın kuramsal yaklaşımı, yukarıda verilen metodolojik tartışmalar göz önünde bulundurularak belirlenmiştir. Buna göre çalışmanın kuramsal boyutunu, Cole (1999)'nin sosyolojik bakış açısının formülü olarak sunduğu; toplumsal yap $1 \rightarrow$ ruh hali $\rightarrow$ davranış yaklaşımı oluşturmaktadır. Bu yaklaşım, toplumsal yapının (toplumun) bireyi etkilemesiyle, bireyde oluşan ruh hali ve bunun sonucu olarak da ortaya çıkan davranışların da, toplumu etkilediğini göstermektedir. (Yazıc1, 2011: 4 ) Bu kuramsal tercih, Doğu Anadolu Bölgesi'ndeki göçer toplumsal yapıyı ve bu yapının yaşadığı çöküşü, böyle bir sosyolojik perspektifin en iyi şekilde açıklayabileceği düşünülerek yapılmıştır.

Burada belirtilen kuramsal yaklaşım bağlamında küçük boy bir toplumsal yapı örneği olarak Doğu Anadolu Bölgesindeki göçer toplum yapısı ele alınmakta ve tahlil edilmektedir. Önce, göç, göçer ve göçebelik kavramları açıklanmak ve bu bölgede göçerliğin bir yaşam tarzı ve ekonomik faaliyet olarak seçilmesinin nedenleri üzerinde durulmaktadır. Ayrıca, bu yaşam tarzını yürüten toplulukların merkezi yönetimlerle ilişkisi ele alınmaktadır. Daha sonra, göçer toplum yapısı, bu yapının yaşadığı değişim, çözülme ve çöküş süreçlerinin analiz edilebilmesi için öncelikle toplumsal değişim, çözülme ve çöküş kavramları kısaca açılanmaktadır. Göçer toplum yapısının yaşadığı çöküşün belli bir kuramsal yaklaşım ve sosyolojik kavramlarla değerlendirilmesi sonucunda ulaşılan veriler, kitle iletişim araçlarının yaygınlaşması sonucunda dış etkenler ve bireysel isteklerle daha çok karşılaşan günümüz toplumsal yapılarında yaşanacak çöküşlerin, zamanında ve doğru anlaşılmasına, olacakların öngörülmesine katkıda bulunacaktır. Buna bağlı olarak, varılan sonuçlardan, toplumsal çözülme ve çöküş aşamasında, zamanın ve maddi kaynakların etkili ve verimli kullanılmasını sağlayacak çözümler geliştirmek amacıyla yararlanılabileceği düşünülmektedir.

\section{DOĞU ANADOLU BÖLGESİ'NDE GÖÇER TOPLULUKLAR}

Göçerler/göçebeler, göç merkezli bir yaşam tarzını seçen ve hayvancılıkla geçinen insanlar, göçebe topluluklarıdır. Göçebelik, göçerlerin, hayvanlarını daha iyi beslemek ve korumak için yer değiştirme durumlarıdır. Göçün temelinde yer değiştirme olgusu bulunmaktadır.

Göç, göçer ve göçebelik kavramlarının tanım ve açıklamalarına ilgili literatürde geniş bir yer verilmektedir. Uluslararası Göç Örgütü (IOM)'ne göre göç, uluslararası bir sınırı geçmek veya devletler içinde yer değiştirmektir. Süresi, yapısı ve nedeni ne olursa olsun insanların yer değiştirdiği nüfus hareketleridir. Buna; mülteciler, yerinden edilmiş kişiler ve ekonomik göçmenler dahildir ( IOM, 2009: 22.). IOM, göçebeyi (nomad) ise, genelde su, gida veya otlak aramak amacıyla bir yerden başka bir yere göç eden bir grubun mensubu birey olarak tanımlamaktadır ( IOM, 2009: 22.). Türkçe sözlükte göçebe; "1. değişik şartlara bağlı olarak belli bir yöre içinde çadır, hayvan ve öteki araçlarla yer değiştiren, yerleşik olmayan (kimse veya topluluk), göçer, 2. mevsimlere göre ülke veya yer değiştiren" (TDK 1998, 863) şeklinde ifade edilmektedir.

Hançerlioğlu (1986: 158)'na göre göçebelik, yaşamak için gerekli koşulları bulmak amacıyla sürekli olarak yer değiştirmek zorunda kalan toplumların yaşam biçimidir.

Göçebelik, dünyada yürütülen en eski ekonomik faaliyettir (Khazanov,1984). Hem Dünya'da hem de Türkiye'de, göç merkezli bir yaşamı tercih eden göçebe topluluklar hep var olmuştur. Dünya'da avcılık ve toplayıcılık dönemini yaşayan göçebe topluluklar ile ticari veya alış - verişçi göçebeler olan Çingeneler ve Arap yarımadasında çöl göçebeleri olarak da adlandırılan Bedeviler ve Kuzey Afrika'da Berberi (Tuareg)ler bu topluluklara örnek olarak verilebilir (Yılmaz ve Telci, 


\section{F.Ü. Sosyal Bilimler Dergisi 2016-26/1}

2010). Türkiye'de ise, Doğu Anadolu'da, bazı “göçebe Kürt aşiretleri”, Güney’de "Türkmenler” ve Ege'de "Yörükler" ve "Çingeneler" (Tezcan, 1969: 131) göçebe hayat tarzını sürdürmektedirler.

Göçün farklı nedenleri ve amaçları vardır. "Savaşlar, fetihler, kıtlık, büyük salgınlar, önemli iklim değişiklikleri, ideolojik baskılar, tehcir, transhümans, avcılık, toplayıcılık, göçebe çobanlık, kentleşme, işsizlik gibi etkenler göçe neden olurlar" (Emiroğlu ve Aydın, 2003: 341-342).

Çalışmanın evrenini oluşturan Doğu Anadolu Bölgesi'ndeki göçebe toplulukların amacı, daha çok tarım için uygun olmayan alanlarda, insanların ve hayvanların ihtiyaçlarını karşılamak için hayvanlara su ve otlak aramaktır. Bu faaliyetin sonucunda, hayvan sürülerinden peynir, yoğurt, tereyağı gibi süt ve süt ürünleri ile et, deri ve yün elde edilerek topluluk üyelerinin ihtiyaçları karşılanmaktır. Yaptıkları faaliyetin yönünü ve sonucunu ise tabiat şartları belirlemektedir.

$\mathrm{Bu}$ bölgede, göçerliğin bir yaşam tarzı ve ekonomik faaliyet olarak seçilmesinin en önemli nedeni, bölgenin coğrafi şartları ve sahip olduğu coğrafi potansiyeldir. Doğu Anadolu Bölgesi'nde göçebe yaşamı mümkün kılan iklim ve bitki örtüsü farklıllğı, coğrafi nedenlerden kaynaklanmaktadır. Bu nedenlerin başında yükselti gelmektedir. Yükseltinin kısa mesafelerde değişmesi ve dağlık alanların fazlalığı, yaz ve kış mevsimleri arasında birbirinden farklı iklim değerlerinin görünmesine sebep olmuştur. Bu da bio-klimatik bakımdan farklı zonlar oluşturarak, hayvancılık açısından yıl içerisinde iki geçim sahası hazırlamıştır. Bunlardan birincisi, alt zonda genellikle kışlık olarak kullanılan köyler ve arazileri, ikincisi ise üst zondaki dönemlik yerleşmeler ile yayla ve mera alanlarıdır. (Tunçdilek, 1967: 21). "İki zon arasında devrilik veya başka bir tanıtımla salınım, kendini sadece doğa yapısında değil, bu doğa koşulları üzerinde yaşayan insan üzerinde de sürdürür. Isı ve bitkiler iki zon üzerinde yıl içinde nasıl salınıyorsa, insan ve uğraşısının da bu salınım içinde kaldığı, sosyo-ekonomik yapısının bu etkiye göre biçimlendiği gözlenir" (Tunçdilek, 1978: 47) "Kışın alçak vadilerde, kapalı depresyonlar kışlık olarak değerlendirilmiş, yazın ise vadi ve depresyonların üst başında kalan platolar ve dağlar yayla (yaylak=yazlak) olarak kullanılmıştır." (Tunçdilek, 1978: 55). "Görülüyor ki Doğu Anadolu ve bilhassa onun muayyen bazı sahalarında, insan, tarla ziraatinden ziyade hayvancılığa bağlıdır. Filhakika bu bölgede geniş ve boş arazi, mera, çayır ve meraların bolluğu, ziraata gayri müsait bir iklim ve nihayet nüfusun tenhalığı hayvan bakımını teşvik eder" (Erinç, 1953: 42). Kaliteli bitkilerin oranının Doğu Anadolu ve Karadeniz Bölgeleri'nin otlak alanlarında \% 70-80, Orta Anadolu steplerinde ise \% 15-20 olduğu rapor edilir (Yalçı, 1986: 10).

Bölgenin sahip olduğu coğrafi potansiyelin bir sonucu olan göçebeliğin, bir yaşam tarzı ve ekonomik faaliyet olarak, İlkçağ' dan beri sürdürüldüğü bilinmektedir. "Bu göçebelik türü tarihçiler tarafından 'kapalı göçebelik' olarak vasıflandırılmıştır (Rowton, 1974). Bununla Rowton; İrani ve Arap platolarına özgü "açık" göçebelik şeklinden uzak ve bunun yerine, Mezopotamya'nın steplerinde ve dağlarında "kır hayatı sürdüren özel bölgelerde" yerleşik şehirli-medenilerle doğrudan temas halinde, sosyo-ekonomik bir örgütlenmeye göndermede bulunmaktadır. $\mathrm{Bu}$ çalışmaların çoğundan, mevsimlik- bölgelerarası dikey göçlerin dört büyük eksende olduğu görülmektedir. Dört rota birbirinden ayrı aşiretler tarafından oluşturulmaktadır:

- Beritan Aşireti, Bingöl rotasında bulunur.

- Alikan ve Amadîsler Bitlis rotasını gösteren aşiretlerdir.

- Dudiranlar, Şırnak rotasını gösteren aşirettir.

- Sonuncusu, Ermeni sınır bölgesince, uzun rotalı-mevsimlik Kürt çobanlar bulunur, ki bu rotalar Iğdır düzlügünden Ağrı, Kars ve Ardahan dağlarına kadardır. Bu bölgede örneklenebilecek tek başına bir aşiret tanımlanmamıştır" (Thevenin, 2011).

1990'lara kadar bölge ekonomisinde hayvancıllğın ve özellikle de "koyun ve keçi Türk ekonomisi ve insanların beslenmesinde önemli bir yere sahiptir" (Yalçın,1986: 1).

Bölgedeki göçerlerin "yayla, mera ve ulaşım" (Çakır,1989: 53) başlıkları altında toplanabilecek sorunları ve karşılaştıkları zorlukların önemli bir kısmının kaynağı yine coğrafi şartlardır. "Kışların fazla uzun sürmesi dolayısıyla hayvanların bu uzun zaman boyunca 
bulundukları yerde beslenmeleri zarureti, yani büyük miktarda yem ihtiyacı, şiddetli soğuklar veya kurak devrelerde hayvanların kırılması, mahfuz ahırlara ihtiyaç duyulması, bu faaliyetin hacmine bir hudut çizer. Diğer taraftan, bu menfi amillere, bozuk münakale şartları dolayısıyla, ziraat için bahis mevzu olduğu gibi, hayvan ve hayvan mahsulleri ticaretinin de sönük ve daha ziyade mahalli ölçüde kalması mecburiyeti ilave edilmelidir" (Erinç, 1953: 42-43).

Bölgenin coğrafi potansiyelinin kaynaklık ettiği göçerlik, kadim bir yaşam tarzı olmasına rağmen, merkezi yönetimlerin, göçebeleri yerleşik hayata geçirmek için, zaman zaman çeşitli tedbirlere başvurdukları tarihi kaynaklarda yer almaktadır. Bazı tarihçiler, bu yöndeki baskılara ekonomik gerekçelerle başvurulduğunu ileri sürmektedirler. Örneğin, Emecan (2000: 114)'a göre, "devlet nizamının bir gereği olarak, başı boş grupların ekonomik gerekçeler dairesinde belirli bir yere iskanı için baskı uygulandığı bilinen bir gerçektir." Ancak, 19. yüzyılın, daha çok ikinci yarısında uygulanan Fırka-i Islahiye "1slah-1 aşair", yani aşiretlerin sslah edilmesini hedefleyen düzenlemeler, bu yöndeki baskıların sadece ekonomik nedenlerle açılanamayacağını göstermektedir. Fırka-i Islahiye düzenlemesiyle; vergi borçlarının tahsil edilmesinin yanında, nüfus sayımının gerçekleştirilmesinin, asker kaçaklarının askere alınmasının ve konumuzu doğrudan ilgilendiren Osmanlı-İran sınırında her iki tarafın egemenliklerini ihlal ettiği belirtilen aşiretlerin hareketliliklerinin denetlenmesinin ve bazı aşiretleri iskan ettirmenin amaçlandığı belirtilmektedir (BOA/Başbakanlık Osmanlı Arşivi).

Göçerlerin bölgedeki hareketliliğine bakıldığında, imparatorluklar döneminde göçerlere yapılan baskıların beklenen sonuçları vermediği anlaşılmaktadır. Bu dönemden sonra, toplumu tek merkezden kontrol ederek, yönetme anlayışını esas alan ulus devletler ortaya çıkmıştır. Ulus devletlerle birlikte, bir taraftan devletlerin belirlenen sınırları, göçerlerin hareket alanlarını daraltırken diğer taraftan göçerlere uygulanan baskılar artmıştır. Alagöz (1938: 37-38), Cumhuriyet'in ilk yıllarında, göçebeleri yerleşik hayata geçmeye zorlamak amaciyla alınan tedbirleri ve ortaya çıkan sonuçları şöyle dile getirmektedir: "Eski Osmanlı İmparatorluğu ülkesi içinde Türkiye Cumhuriyeti, Irak, Suriye sinırları teşkil etti. Çobanların, sürülerle devlet sınırlarından geçmesi, karşılıklı anlaşmalarla kolaylaştırılmış bulunuyorsa da, bu sınırlar, hayvan beslemekle ömür geçiren grupları az çok tespit etmiştir. Anadolu'nun evvelce görmediği sıkı bir idari organizasyon, aşiretleri yerleştirme politikası, sayım vergisi gibi vergiler, serbest aşiretlerin hareketlerini tehdit ve onları yerleşmeye icbar etmiştir. Böylece Osmanlı İmparatorluğunda göçebelik yapan aşiretler, yaylacılıkla iktifaya başlamışlar, yaylacılık da nüfusun veya ziraatın artması ile yer yer önemini hafifletmiştir (Afyonkarahisarın Emirdağında). Nihayet, 1937 Şubatında neşredilmiş olan orman kanunumuz, dağlarda, ormanların içindeki otlaklardan istifadeyi tehdit etmiş ve yayla demek olan orman sahaları askeri kontrol altına alınmıştır."

Göçebelerin yerleşik hayata geçirilmesi çabalarının imparatorluklar döneminde başladığı, ulus devletlerin ortaya çıkmasıyla da yoğunlaştı̆̆ ve ekonomik gerekçelere dayandırılan çeşitli tedbirlerin alındığı anlaşılmaktadır. Bu tedbirlerden bazıları şunlardır:

- $\quad$ Sik1 bir idari organizasyon kurmak,

- Çeşitli isimler altında vergiler almak,

- $\quad$ Ziraatı teşvik etmek ve ziraat alanlarını genişletmek,

- $\quad$ Orman ve mera kanunları çıkararak göçerlerin yaşam alanını daraltmak,

- Göçebelik yapılan alanları askeri kontrol altına almak.

$\mathrm{Bu}$ faktörler arasında, Türkiye'de meraların hükümetler tarafindan yeniden düzenlenerek denetlenmesi yönünde yoğunlaşan uygulamalar, göçebelik faaliyetini olumsuz etkileyen faktörlerin başında gelmektedir.

Doğu Anadolu Bölgesi'nde göçer gruplara; bu tedbirlere ilaveten, çeşitli ekolojik baskılar (nüfus artışı, yaylak ve kışlakların kira bedellerinin artışı vs.), (Beşikçi, 1968: 7) İran, Irak, Suriye sınırının karşılıklı olarak göçebe hareketlerine kapatılması, geleneksel yaylaların en yakın köyün kamu malı haline getirilmesi, köylülerin toprak ve yaylak için hükümetten devamlı talepleri ve bu 


\section{F.Ü. Sosyal Bilimler Dergisi 2016-26/1}

taleplerin benimsenmesi (Beşikçi, 1968: 7) gibi nedenlerle seçimini kendilerinin yapmadığ yeni gerçekler dayatıldığı anlaşılmaktadır. "Bates ve Beşikçi'nin çalışmaları, göçerliğin yerleşik toplumlar ve yerleşik tarım üretimi sistemleriyle ne kadar iç içe olduğunu ve göçer-yerleşik bağlarının ne kadar sıkı ve birbirine çevrilebilen bağlar olduğunu da gösteriyor. Gene bu iki çalışmadan öğrendiğimize göre, yaylalar eskiden gelenek olarak çeşitli aşiretlere ait olduğu halde Cumhuriyet sonrasında hızlanan bir süreç içinde özel mülkiyete geçerek göçerlere kiralanmaya başlanmıştır” (Yalçın-Heckmann,1993: 280).

Göçerlerin hareket alanını daraltan bütün bu tedbirlere rağmen, Doğu Anadolu Bölgesi'nde göçebelik faaliyetleri 1980'lere kadar devam etmiştir. Bu bölgede, 1983'te başlayan ve 2013 baharında varılan ateşkesle (barış süreciyle) sona eren 30 yıllık çatışma döneminde, göçebe toplulukların sayısı en alt düzeye inmiştir. Çünkü, bu dönemde hayvancılıkla geçinen birçok köyün boşaltılması ve köylülerin göçe zorlanması, bölgede geniş coğrafi alanları kapsayan barajların inşa edilmesi sonucu, göçerlerin göç yollarının kesilmesine veya uzamasına neden olması, bazı meraların güvenlik gerekçesiyle uzun yıllar boyunca göçerlik faaliyetlerine yasaklanması, göçerlik faaliyetini engelleyen başlıca politikalar olarak uygulanmıştır.

Sonuç olarak, merkezi yönetimlerin göçerleri yerleşik hayata geçirme çabalarının, devletlerin, egemenlikleri altında yaşayan bireyleri, daha çok da grupları "kontrol altına almak ve denetlemek" istemelerinden kaynaklandığı anlaşılmaktadır. Bu amaçla, zaman zaman talimatnameler çıkarmak, nüfus sayımı yapmak, erkekleri askere almak ve çeşitli isimler altında vergiler toplanmak gibi tedbirlere başvurulduğu anlaşılmaktadır. Ancak, göçerleri, yaşam tarzlarından dolayı, baskı ve zorlamalarla kontrol altına almanın ve denetlemenin mümkün olmadığı görülmektedir.

Göçer toplulukların merkezi yönetimlerin baskı ve zorlamalarına karşı bu kadar uzun bir süre direnebilmeleri, bu toplulukların yaşadıkları bölgenin coğrafi koşulları, yürüttükleri faaliyetin özellikleri ve meydana getirdikleri toplumsal yapı anlayışı, toplumsa örgütlenme ve ilişki kurma biçimleriyle açıklanabilir.

\section{GÖÇERLERDE TOPLUMSAL YAPI, DEĞIŞ̧IM, ÇÖZÜLME VE ÇÖKÜŞ}

Çalışmanın bu bölümünde önce, toplumsal değişim, çözülme ve çöküş kavramları kısaca açıklanacaktır. Daha sonra, göçer toplum yapısı ve bu yapının toplumsal örgütlenme biçimi verilecek ve bu kavramlar bağlamında tahlil edilecektir.

\subsection{Toplumsal Değişim, Çözülme ve Çöküş}

Toplumsal değişmenin esası yeniliktir (Dönmezer, 1982: 428). Toplumsal değişme sürecinde, toplumsal yapıda "eski kurumlar çözülür veya biçimlerini tümüyle değiştirirler. İnsanın çevresi ve arkadaşlarılla ilişkileri her nesille birlikte başkalaşır. Eğilimler, adet ve gelenekler, inanç ve deneyimler, bu başkalaşmaları toplumsal yapıda yansıtıyormuşçasına birbirlerini izlemişlerdir. İletişimde, eğitimde, üretim ve tüketim alışkanlıklarında, savaşta, hak-hukukta, sanatta, yönetimde, aile yaşamında, vergilendirmede, boş zaman değerlendirmesinde, giyside, bireysel davranışta, diğer bir değişle her alanda her nesille artan ve atalarının omuzlarında yükselerek ağırlıklarını yaygınlaştıran yenilikler ve değişimler görmekteyiz" (Smith, 1996: 87).

Geleneksel toplumlar değişme hızı az, dengeli toplumlardır. Buna karşılık, çağdaş dinamik toplumlarda toplumsal değişme çok hızlıdır ve yoğundur (Dönmezer, 1982: 447), etkilidir, süreklidir, "fakat aynı zamanda çeşitlilik gösterir ve görünüşte önceden belirlenemezdir. Toplumun her düzeyinde ortaya çıkar, hız ve kapsamda çeşitlilik gösterir, hem niceliksel hem de niteliksel olarak sınıflandırılabilinir. Bunun ötesinde değişmeler globaldir. Çağdaş değişmeyi önceki örneklerden farklı kılan şey işte budur" (Smith,1996: 87).

Çağımıza özgü yeni değişim faktörlerinin de eklenmesiyle, günümüzde, toplumsal yapıların, daha önceki dönemlerle kıyas kabul etmeyecek düzeyde hızlı değiştiği; buna bağlı olarak zihinlerin yeniden inşa edildiği, ilişkilerin yeniden düzenlediği ve toplumsal yapıların yeniden kurulduğu anlaşılmaktadır (Yazıcı, 2013b:1493). Günümüzde ortaya çıkan yeni değişim faktörleri, toplumsal 
yapıların değişim hızını artırmakta, yapıyı meydana getiren öğelerin aynı hızda ve uyumlu bir şekilde değişmesini önlemektedir. Bu durum, çağdaş toplumsal yapılarda çatışmaların daha yıkıcı, çözülmelerin daha hızlı, yapıların daha kısa ömürlü olmasına ve toplumsal çöküşlerin daha sık yaşanmasına neden olmaktadır. Çünkü, "günümüzde milyarlarca insan, bizi her zamankinden hızlı bir şekilde ve kökten değişmeye zorlayan teknolojik gelişmeler ve diğer büyük değişiklikler denizi içinde boğulmaktadır. Bu zorlamalar, dünyanın dört bir yanındaki geleneksel halklar için daha da rahatsız edicidir; çünkü bu değişimler genellikle güçlü dış kuvvetler tarafından bu halkların geleneksel yaşam biçimlerinin altı oyularak ve seçimini kendilerinin yapmadığı yeni gerçekler yaratılarak dayatılmaktadır" (Haviland, vd., 2008: 739).

Değişme aslında, yeni bir denge ve uyum arayışıdır. Çünkü toplum hayatında uyum olmadığı veya uyumun egemen olmadığ 1 durumlarda toplum ya çözülmüş ya da çözülüyor demektir (Ozankaya, 1999:13). Toplumsal çözülmenin önlenemediği yapılarda ise çöküş meydana gelir.

Ne toplumsal çözülmeyi ne de çözülmeyi engelleyecek nedenleri tek faktörle açılkamak mümkün değildir; çünkü, "çözülmeye zemin hazırlayan faktörler çeşitlilik arz etmektedir. Çözülmeyi önleyici tedbirler de aynı şekilde çeşitlidir. Örneğin; Durkheim, çözülmeyi önlemek için işbölümüne ağırlık vermektedir. Ancak, işbölümünün geliştiği, maddi refahın arttığ 1 ülkelerde bile çözülme haline rastlanabilmektedir. $\mathrm{Bu}$ da, maddi hayatın iyileştirilmesinin ve düzenlenmesinin çözülme eğilimlerini yok etmediğini göstermektedir. Sorokin, çözülmenin kültürel hedeflerde sağlanacak mantıki-manalı bir bütünleşmeyle önlenebileceğini savunur" (Türkkahraman ve Tutar, 2009: 10). Durkheim'a göre, "bireyin istekleri ile toplumun düzen ve kontrol ihtiyaçları arasında temel bir çatışma ve gerilim her zaman var olacaktır" (Slattery, 2007: 35). Bu çatışma ve gerilimle varlığını sürdürmekte başarılı olamayan toplumsal yapıların ömrü toplumsal çözülme ve çöküşle son bulur.

Literatürde, toplumsal çöküş, daha çok büyük boy değişim kuramlarıyla açıklanmaktadır. Büyük boy toplumsal değişim kuramı örneklerinden biri, İbn Haldun (2011: 392-401)'un, yükseliş ve çöküş yaklaşımıdır. Bu yaklaşıma göre, devletler bir organizma gibi doğar, büyür ve ölürler (Okumuş, 2007). Diğer bir örnek, Spengler (1997: 128)'in, "her oluşan şey ölümlüdür" önermesiyle ifade ettiği organizmacı yaklaşımıdır. Spengler'e göre, "kültürler organizmalardır ve dünya tarihi bunların ortaklaşa biyografisidir. Her kültür, bireylerin yaş dönemlerinden geçer. Hepsinin doğumu, çocukluğu, gençliği, olgunluğu ve yaşlılı̆̆1 vardır” (Spengler, 1997: 108). Spengler bu konuda, "bilhassa çağımızda ve dünyamızda bütünleşme safhasında tek olan batı Avrupa- Amerika kültürünün- kaderindeki el değmemiş aşamalarını" izleyerek ortaya koymaya çalıştığını ileri sürmüştür (Spengler, 1997: 19).

Konuyla ilgili bir diğer örnek, "bütünleşmiş toplumların bir sonucu olan medeniyetlerin çöküşü üç aşamada gerçekleşir" (Okumuş, 2007: 218) diyen Toynbee'nin geliştirdiği yaklaşımdır. Toynbee, "medeniyetlerin hareketlerinin çevrimsel ve tekrarlayıcı olabileceğini söylemekle birlikte, çöküşün kaçınılmaz olmadığını; çevrimsel kaderciliğe mahkum olmadığını; ölen medeniyetlerin kaderleri öyle olduğu için değil, başka birtakım nedenlerle öldüklerini iddia etmektedir" (Okumuş, 2007: 218). Ona göre, medeniyetler için "kendini belirleme yeteneğini kaybetmek, çöküşün nihai ölçütüdür” (Toynbee, 1978: 182).

Sorokin'e göre, kültür "sistemlerinden her biri, siyasal, estetik, ahlaki ve bilişsel değerler alanındaki yaratıcılığını tükettiği ve egemenliğini, yaratıcı faziletlerle sürdürecek yerde, hareketsizlik, zorlama, sahtekarlık ve sahte değerlerle bunu sağlama yoluna saptığı zaman, verimsiz, çoğu zaman zararlı hale gelir. Bu durumda gerek üyelerine gerekse insanlığa bir yarar sağlamaz duruma düştügü için, çöker”(Kongar, 2012b: 125).

Toplumsal çöküş dönemleri, mevcut ve alışılmış olanın bozulduğu, sosyal bireyin ve toplumsal yapının kaderlerinin yeniden şekillendiği; geleceğin belirsiz hale geldiği bunalım dönemleridir. "Normal zamanlarda bile, en azından birkaç düşünür veya bilgin, insanın kaderi üstünde kafa yorar. Toplumsal çöküşün yaşandığı ciddi bunalım anlarında ise, bu sorunlar 


\section{F.Ü. Sosyal Bilimler Dergisi 2016-26/1}

birdenbire, teorik olduğu kadar pratik, düşünürler için olduğu kadar sıradan halk için de olağanüstü bir önem kazanır" (Sorokin, 1972: 21). Sorokin'in ifadesiyle, "insanlığın bütün tarihindeki muhtemelen en büyük bunalım dönemi olan yirminci yüzyıl"da (Sorokin, 1972: 24) toplumsal çözülmeyle ilgili çok sayıda çalışma yapılmıştır.

\section{2. Göçerlerde Toplumsal Yapı}

Toplumsal yapı, içinde sosyal ilişkilerin kurulduğu, toplumsal olayların meydana geldiği; karşılıklı ilişkiler içinde bulunan sosyal grupların (Yazıcı, 2011: 463) ve "toplumsal kurumların az çok bütünleşerek oluşturduğu bir düzendir” (Boran ve Yasa'dan akt. Gökçe, 2004: 7). Kıray (1964: 6)'a göre ise, "ister ilkel, ister feodal, ister modern temel yapıda ya da bunların değişim içindeki çeşitlenmeleri halinde olsun, her sosyal yapı, bu yapıyı meydana getiren sosyal müesseselerinden, insan ilintilerinden ve bunların karş1lklı münasebetlerinden doğan sosyal değerlerin birbirlerini karşılıklı etkiledikleri bir bütündür." Bütün olma özelliğiyle belirginleşen toplumsal yapı, "her an, onu oluşturan "yapı taşları"- sizin ve benim gibi insanlar- tarafından yeniden kurulur" (Giddens, 2000: 6). Toplumsal yapı ve bireyler arasındaki bu ilişkide, "yapı devasa fakat görünmez bir güçtür, insanlar üzerinde etkili olan, davranışlarını, duygularını, kimliklerini, algılayışlarını belirleyen bir tür sosyolojik çekim kuvvetidir" (Agger, 2011: 83).

Her toplumsal yapının bir düzeninin olması, toplumun bir yığın, şekilsiz bir kümeleşme olmadığını göstermektedir. Bundan dolayı, "toplum yapısı, ne sadece basit bir varlık olarak ve ne de sert bir şekilde yekpare kalıplaşmış çok sıkı tesanütle kaskatı, donuk tamlaşmış durumdadır. Bilâkis, son derece yumuşak, eğilip bükülmesi mümkün, katılmaları kolaylaştıran, geçişleri sağlayan bir yapıya sahip bulunan toplum daima değişme niteliğine ulaşmak ister" (Nirun, 1991: 107).

Yukarıda verilen tanımlarda görüldüğ̈̈ üzere, toplumsal yapının farklı noktaları ön plana çıkarılmaktadır. Bu tanımları birlikte değerlendirdiğimizde; toplumsal yapının içinde sosyal birey, grup ve kurumların yer aldığı, sosyal etkileşimlerin gerçekleştiği, dinamizmi, toplumsal yapının üyeleri olan bireyler tarafından sağlanan, geçişken, sürekli değişen ve yenilenen, belli bir düzeni olan yapılaşmış bir bütün olduğu sonucuna varılmaktadır. Bir yapının içinde yer alan bu öğelerin önceliği ve ilişkide olma biçimleri yapıdan yapıya, hatta aynı toplumsal yapıda zamanla değișmektedir. Bu değişiklik, üyelerin ihtiyaçları, ihtiyaçların karşılanma biçimi, sahip olunan imkanlar, kullanılan araçlar ve başka toplumlarla etkileşimin düzeyi gibi faktörler tarafından belirlenmektedir.

Toplumsal yapı bireylerden önce vardır. İnsan hayatı bir toplumsal yapı içinde başlar, bu yapı içinde öğrendiği değerlerle şekillenir ve anlam kazanır. Gündelik hayatla onu kapsayan toplumsal yapı arasındaki ilişki, bireylerin davranışlarını şekillendirir ve böylece bireylerin benlik kazanmalarını sağlar. Bu durum, sosyolojik bir bakışla değerlendirildiğinde, bireysel olarak kabul edilen benliğin, daha çok toplumsal bir ürün olduğu sonucuna varılır. Çünkü insanların içgüdüleri, düşleri, özel düşünceleri olmasına karşın aile, eğitim ve dini kurumlar, sınıf, ırk, cinsiyet, kuşak, ulus gibi önemli sosyal gruplara üye olmak, insan yaşantısı üzerinde ağır etki bırakır (Agger, 2011: 69), ancak, bu ağır etki, bireysel farklılıkları ve bireyin belirleyici olma gücünü yok etmez. Bu durum, fail ve yapı diyalektiğinin bir kez daha dikkate alınması gerektiğini ortaya koymaktadır.

Bir toplumsal yapının; coğrafi konumu, teknolojik gelişimi, inancı ve siyasi yönetimi gibi özellikleri, o yapının diğer toplumlarla etkileşim düzeyini etkilemektedir. Ancak, tamamen dış etkilere kapalı, izole bir yapı söz konusu değildir. Yalnız, geleneksel dönemde yapıların etkileşimi ve yapılara yeni öğelerin katılması alt düzeyde gerçekleşirken, günümüzün modern ve postmodern toplumlarında en üst seviyede gerçekleşmektedir. Bundan dolayı, çağdaş toplumsal yapıların ömrü çok daha kısadır ve daha fazla toplumsal çöküş örnekleri yaşanmaktadır.

Toplumsal yapıların ortak ve benzer özellikleri olmasına rağmen, her yapıyı diğerlerinden farklı kılan temel özellikleri vardır. İbn-i Haldun'a göre, toplumsal yapıların çap ve yoğunluğunu 
belirleyen değişken grup duygusu, grup dayanışması (asabbiye)dir (Stowasser, 1984: 175). Göçerlerin grup dayanışmasını yansıtan örgütlenme biçimi, aşiret sistemidir.

Göçer toplum yapısı, bölümleri birbirine nedensel ve anlamlı bağlarla bağlı, dişa kapalı, birleşmiş bir sistemdir. Bu sistemde amaç, iç ve dış tehditlere karşı yapının bütünlügünü korumak ve aile için (geçimlik) üretim yapmaktır. Etkileşim düzeyleri yerleşik gruplara oranla daha zayıf olan göçer grupların her biri, bir toplumsal yapı niteliğindedir. Bu yapılar, bir üst sistem olan aşiret örgütlenme sistemi içinde yer alırlar. Bundan dolayı, bölgenin; coğrafi potansiyelini, bu potansiyeli değerlendiren ekonomik faaliyet olarak göçerliği ve sosyolojik yapısını araştıranlar, ilk olarak aşiret olgusuyla karşılaşmaktadırlar.

Doğu Anadolu Bölgesi'nde, insanların tarih boyunca ihtiyaçlarını karşılamak için, bölgenin doğal/coğrafi potansiyelini kullandıkları, bu amaçla ekonomik faaliyet olarak göçerlik yaptıkları ve örgütlenme biçimi olarak da aşiret sistemini geliştirdikleri anlaşılmaktadır. Aşiret sisteminin kendine özgü "anlamlar" ve "değerler" ürettiği, üyelerinin (faillerin) eylemlerini ve etkileşimlerini buna göre değerlendirdiği; onaylanan davranışların ve ilişkilerin ödüllendirildiği, onaylanmayanların ise toplumsal kontrolle baskı altına alındığı ve sapma davranışlara çeşitli müeyyidelerin uygulandığı görülmektedir.

Yalçın-Heckmann (1993: 278) aşireti, "birbirine bir şekilde akraba olduğuna inanan, birbirine karş1 çeşitli yükümlülükleri ve ortak bir 'ahlak' (moral) kodları olan bir toplum” olarak tanımlamaktadır. $\mathrm{Bu}$ toplumların/toplumsal yapıların her biri kan ve akrabalık bağları ile bağlanmış, kendi içinde bağımsız olan ilkel bir idare şekline sahiptirler. (Dizadji, 1973: 6). Bu özellikleriyle millet altı örgütlenme biçimi olarak da tanımlanan aşiret sistemi bölgenin sosyal ve tarihsel bir gerçeğidir. "Osmanlı arşiv belgelerine göre, ülkemizde 7230 kadar aşiret vardır. Günümüzde, bu millet-altı kuruluşlar Doğu ve Güneydoğu bölgemizde hususiyetlerini önemli ölçüde sürdürmektedirler. Bölgenin yaklaşık $\% 25$ 'i, bu aşiret oluşumunun içinde yaşamaktadır" (Taşdelen, 1997: 5). Dinamik bir topluluk olan göçerler için aşiret sistemi, dışarıdan gelecek tehditlere karşı korunma, içerde sosyal dayanışma ve sosyal kontrolü sağlamak gibi toplumsal yapının varlığını sürdürmesi için gerekli olan birçok işlevi yerine getirmektedir. Anadolu'nun ekonomik yapısı içinde ürettikleri hayvan potansiyeli ve ürünleri ile önemli bir yer ve etkinlik elde eden göçerlerin, varlıklarını asırlarca sürdürmelerinde aşiret sisteminin belirleyici olduğu sonucuna varilmaktadir.

Araştırmasını 1960'larda yapan Beşikçi (1968, 26), Doğu Anadolu Bölgesi’ndeki aşiretlerin sayılarının ve nüfuslarının bilinmediği belirtilmektedir. Ona göre, göçerler "sayım esnasında yaylalarda, yüksek dağlarda, şehir, kasaba, köyden çok uzaklarda bulundukları için sayıları kaydedilemiyor. İlk iş olarak bunların sayılarını saptamak gerekir." Aşiretlerin, ancak 1990'ların başından itibaren, nüfus sayımına dahil oldukları ve oy kullandıkları tespit edilmiştir (Çakır, 1989: 47). Bu tespit, 1990'ların başına kadar Doğu Anadolu Bölgesi'nin, "göçebe ve yarı göçebe hayat süren aşiretlerin yoğun olduğu bir mekan dokusuna sahip" (Çakır, 1989: 42) olduğunu göstermektedir.

Genelde aşiretlerde, özelde ise göçer gruplarda, sosyal ilişkilerde geleneksel davranış kalıpları, üretimde geleneksel araçlar kullanılmaktadır. Göçer toplum yapısında, yeni teknolojilerin üretilememesi veya üretilmiş yeni teknolojilerin kullanılamaması, fiziksel koşullar, teknolojik imkanlar, bu yapıların başka toplumlarla etkileşimden uzak olmaları ve yapıyı oluşturan nüfusun özellikleriyle açıklanabilir. İbn-i Haldun (2011: 329-330)'a göre, göçerlerin genel özellikleri cesur, çalışkan, refah ve lüksten uzak, kendilerini ve mülklerini, dışarıdan silahlı bir güce ihtiyaç duymadan kendileri koruyan, yönetimle ilgili kuralları kendileri belirleyen ve yerleşiklerin aksine, duvarların arkasında yaşamak yerine, doğayla iç içe yaşamalarıdır. Beşikçi (1968: 2), çalışma kapsamında ele alınan göçer toplulukların 1960'ların sonlarında sahip oldukları özellikleri hakkında şu tespitlerde bulunmaktadır: Ekonomik bir faaliyet olarak göçebeliği tercih eden topluluklar, sosyolojik ilişkileri kapalı ekonomiye sahip, kan akrabalığı ve birlik duygusu gibi bağlarla birbirine bağl1, bir şefe bağlanan, okuma yazma bilmeyen geleneksel gruplardır. 


\section{F.Ü. Sosyal Bilimler Dergisi 2016-26/1}

Göçer toplum yapısının ayır edici bir özelliği de, insan/toplum - doğa ilişkisi sonucu şekillenmiş bir yapı olmasıdır. Bundan dolayı, bu yapıya asıl biçimini veren faktörlerin başında, bölgenin doğal kaynakları olan hava, su ve bitki örtüsünden yararlanma amacı gelmektedir. $\mathrm{Bu}$ kaynakların özelliği ise iklim koşullarına göre değişkenlik göstermeleridir. İklim koşullarına bağlı olarak, belli bir güzergah üzerinde ve belli aralıklarla yer değiştiren bölgedeki göçer toplulukların temel faaliyetleri, bölgenin doğal kaynaklarından yararlanmak amacıyla koyun sürüleri beslemek, tek geçim kaynakları da bu faaliyet sonucunda elde edilen ürünler olan göçerler, iklim koşullarına göre değiş̧en doğal kaynaklardan yararlanmak için belli aralıklarla yer değiştirmektedirler. Göçerler için yer değiştirmek, hem kendilerinin hem de sürülerinin hayatta kalması için bir zorunluluktur. $\mathrm{Bu}$ zorunluluk, göçer toplum yapısını özgün kılan ve niteliklerini belirleyen temel faktörlerin başında gelmektedir.

Sorokin'e göre (Erkilet, 2013: 16), bir insan grubunun var olabilmesi ve hayatını idame ettirebilmesi bakımından hayatî önem taşıyan siyasal örgütlenme ve toplumsal normların kaynağ 1 olan dinsel sistemlerdir. Göçer toplum yapısında, siyasal örgütlenmeye, aşiret sistemi karşıllık gelmektedir. Göçer toplum yapısında, aile kurumu merkezî bir konumdadır; her aşiretin ve göçer grup birer aile olarak kabul edilmektedir. Toplumsal normların kaynağ 1 olan dinsel sistemler (inançlar), göçer toplum yapısı için de geçerlidir. Bu yapılarda, aile kurumu, normların uygulanmasında da belirleyici role sahiptir. "Görülüyor ki Sorokin, insanlık tarihinin ilk aşamalarında, toplumsal bütünleşme için gerekli olan normları, dinsel normlardan ayırmamaktadır. Bu ilk aşamada toplumsal yapıda farklılaşma yoktur" (Erkilet, 2013: 16). Bu yaklaşıma göre, göçer toplum yapısı, dinsel sistemlerin belirleyici olma özeliğiyle, insanlık tarihinin ilk aşamalarına ait toplumsal bütünleşmeye örnek olarak verilebilir. Çünkü, henüz göçer toplum yapısında farklılaşma ve bunun sonucu olarak temel toplumsal sistemler ortaya çıkmamıştır. ${ }^{2}$

Toplumsal hayat yaşamayı anlamlı ve mümkün kılan; doğaya, bireylere ve davranış kalıplarına anlam yükleme, olumlu anlam yükleme eylemlerinden değerler oluşturma ve değerleri normlarla koruma süreci, göçer toplum hayatından şu örneklerle somutlaştırılabilir: Göçerler, şehirlerin doğal olmayan seslerin oluşturduğu gürültülü ortamına karşl1ık, doğa ve sürüyle baş başa kalmaya, hayatî nitelikte olumlu anlam yüklemektedirler. Bununla birlikte, aşiret liderliği veya göçer grupta aile reisliği (en yaşlı erkek üye) konumuna farklı bir anlam yükledikleri anlaşılmaktadır. Bir davranış kalıbına yüklenen anlama örnek olarak da, yaşça büyük olanın elini öpmek gösterilebilir. Bu davranışa olumlu anlam yükledikleri ve bu davranışın bir değer olarak yüceltildiği, mevcut değere uygun olmayan davranışlar için çeşitli normlar/müeyyideler geliştirdikleri anlaşılmaktadır.

Durkheim, bir toplumdaki bireylerin, olumlu anlam yüklemelerinden doğan değerlerin toplumu anlamadaki belirleyici konumunu şu ifadelerle dile getirmektedir: "toplum, bağımsız bir parçalar sisteminden oluşan diğer organizmalar gibi işler; ancak ekonomi, aile, yönetim vb.den oluşan bu parçaları bir arada tutan şey, merkezi bir sinir sistemi değil, temel bir değerler sistemi, temel bir ahlaki konsensus veya kolektif bilince dayanan, normlar adı verilen bir toplumsal k1lavuzdur" (Slattery, 2007: 34). Bu kılavuz, toplumsal yapıları tanımamızı sağlayacak özelliklere sahiptir. Bundan dolay1, "toplumbilimciler sosyo-kültürel fenomene 'sosyo-kültürel olma' niteliğini kazandıran anlamlar üzerinde odaklanmak durumundadır. Fiziksel özellikleri aynı olan iki davranış, kendilerine atfedilen anlamdan dolayı, çok farklı toplumsal davranışlar haline gelebiliyorsa bu anlam onların aslî niteliklerine empoze edilerek onu geri plâna itebiliyorsa, bu

\footnotetext{
${ }^{2}$ Sorokin'e göre farklılaşma sürecinde şu temel toplumsal sistemler ortaya çıkmaktadır:

a) Doğru ile yanlışı birbirinden ayıran Etik Sistemler;

b) Mülkiyet ilişkilerini, temel hak ve görevleri düzenleyen, yasal olanla suç teşkil eden eylemleri birbirinden ayıran Hukuk Sistemleri;

c) Kutsal ve tabu olanı olmayandan ayıran Dinî Sistemler;

d) Bilgi edinirken gerçekle hatayı birbirinden ayıran Bilimsel Sistemler;

e) Sanat Sistemleri." (Erkilet, 2013:16).
} 
durum, anlam bileşeninin, toplumbiliminin temel inceleme konusu olduğunu gösterir" (Erkilet, 2013: 19-20).

Yapıyı oluşturan diğer öğeler ise, aile ve normlar aracıllğıyla işlevlerini yerine getirmektedirler. $\mathrm{Bu}$ durum, bütünleşmiş bir toplum örneği olarak göçer toplum yapısını anlamak için, öncelikle aile kurumunun anlaşılması gerektiğini ortaya koymaktadır.

Göçer toplum yapısında en temel toplumsal kurum olan aile, yapı ile özdeşleşmiş durumdadır. Çünkü, yapıda belirgin bir farklılaşma meydana gelmemiştir. Bundan dolayı, siyasal örgütlenmenin, organizasyonların ve toplumsal normların kaynağı olan dinsel sistemlerin belirlediği değerler de aile kurumu merkezli olarak şekillenmektedir. Bu tespitten hareketle, göçer toplum yapısında; ailenin, ailedeki statülerin ve rollerin işlevlerinin ve karşıllıklı ilişkilerinin, bunlarla birlikte değerlerin ve normların, yapının genel karakterini yansıttığı ileri sürülebilir.

Göçer toplum yapısının, başka bir ifadeyle bu yapıdaki aile kurumunun, üç temel prensip bağlamında bütünleştiği anlaşılmaktadır. Bunlar: a) Yaşa ve cinsiyete dayalı iş bölümü, b) Bireye karşı toplumun (ailenin) yüceltilmesi, c) Bireysel tercihlerin normlar ve değerler aracıllğılla baskı altına alınmasıdır. Bu üç prensip bir arada değerlendirildiğinde, yapının sürdürülmesinin birinci öncelik olarak belirlendiği, mevcut yapıyı bütün yönleriyle içselleştirmiş yaşlı bireylerin, aile ve yapıyla özdeşleştirildiği, yaşlı bireylerin yapıyı değişim taleplerine karşı koruma misyonu üstlendikleri sonucu ortaya çıkmaktadır. Bununla birlikte, bireysel tercihlerin ve isteklerin, yapıya yöneltilmiş en büyük tehdit olarak algılandığı da görülmektedir. Bundan dolayı, bireysel tercihlerin kontrol altında tutulması amacıyla, bu yöndeki tercihleri yansıtan davranış kalıpları "ayıp" ve "günah" olarak nitelendirilip ortaya çıkması engellenmektedir.

Bölgede "ayıp" ve "günah" olarak kabul edilen en yaygın davranışlar şunlardır: Büyüklerin yanında sigara içmek, şarkı söylemek, ıslık çalmak, saç taramak, tıraş olmak, ayak ayak üstüne atarak oturmak veya uzanmak, büyüklerinin elini öpmemek, nişanlıların bir araya gelmeleri, karşılaştıklarında konuşmaları; dügünden sonra gelinlerin ailenin yaşlıları yanında yiyip-içmeleri, bir kişinin, yaşlıların yanında, eşinden söz etmesi, özellikle de eşinin ismini söylemesi; eşlerin konuşmaları; anne-babaların, çocuklarını sevmeleri veya birbirlerine sevgi gösterisinde bulunmaları, el ele tutuşarak yürümeleri. (Yazıc1, 2013a: 328). Bölgede yapılan bir saha çalışmasında, "ayıp" ve "günah" olarak kabul edilen bu davranışların, "büyüklere saygılı olmak" ve "büyüklerin takdirini kazanmak” gibi amaçlarla yapıldığı tespit edilmiştir (Yazıcı, 2014: 329).

Bireylerin, "ben de varım" mesajı olarak algılanabilecek bu ve benzeri davranışların normlar aracılı̆̆ıyla sosyal kontrolle önlenmesi, "yapının ikili karakteri” paradoksu hatırlandığında, toplumun bütün yönleriyle bireye tercih edildiği sonucu ortaya çıkmaktadır. Göçer toplum yapısında toplumu aile temsil etmektedir.

Aile merkezli göçer toplum yapısında, bir ailedeki kişi sayısı ve ailenin sahip olduğu koyun sayısı; zenginlik, güç ve nüfuz göstergesi olarak kabul edilmektedir. Kişi sayısının önemini, Çakır'ın (1989: 52) göçerlerle görüşmesinde sorduğu “ -Neden bu hayatı seçtiniz?” sorusuna verilen "- İşte, ailemin isteği üzerine oldu bu. Bir de bizim meslek, insan gücüne çok ihtiyaç vardır. Yani, bu mesleği terk eden olursa, bu durum, insan gücünün yetersizliğinden olur" cevabı açıkça ortaya koymaktadır. Bölgede yaygın olarak dillendirilen, "o zamanlar koyunu çok olan zengin kabul edilirdi" ve "sılav ne lı ruyane, sılav lı miyane" (selam "kiş̧i" için değil, kişinin sahip olduğu "koyunlar" içindir) sözleriyle bu durum dile getirilmektedir. Alagöz'ün (1938: 11) 1930’ların sonlarında yaptı̆̆ tespit ise şöyledir: "Doğuda, Cenupta mesela: 'Çok zengin bir adamdır, çiftlikleri ve şu kadar bin koyunu var" denir."

Üyelerinin, yapıya doğum yoluyla katıldığ 1 , dışa kapalı göçer toplum yapısında, kişiler, toplumu bireye tercih eden, "ben" yerine "bizi" empoze eden anlayışı, sosyalleşme sürecinde öğrenmekte, benimsemekte, uygulamalara katılarak zamanla içselleştirmekte, bu yolla diğer üyelerle aynı anlam etrafinda bütünleşmektedirler. Ailenin yaşlı üyeleri olduklarında ise, aynı anlayışla yeni üyeleri sosyalleştirme görevini üstlenmektedirler. Anadolu'da ve özellikle de 


\section{F.Ü. Sosyal Bilimler Dergisi 2016-26/1}

çalışmanın örneklemini oluşturan bölgede, göçer toplum yapısını, bu prensiplerle varlığını, üyeleri farklı yapılarla karşılaşıncaya kadar asırlarca devam ettirdiği anlaşılmaktadır.

Sonuç olarak;

a) Bölgedeki göçer toplum yapısının temel karakteristiğinin, bölgenin coğrafi potansiyeli, iklim ve bitki örtüsü tarafindan belirlendiği,

b) Sosyal örgütlenme biçiminin aşiret sistemi olduğu,

c) Bu yapı ve örgütlenme biçiminde aşireti/aileyi (bizi), bireye tercih eden bir anlayış hakim olduğu,

d) Bölgede kapalı göçebelik yapıldığından, aynı göçer grupların, aynı güzergahı takip ettikleri için, aynı yerleşik topluluklarla ve aynı merkezi yönetimin yöneticileriyle etkileşim içinde oldukları,

e) Göçebe yaşam tarzı ve gereklilikleri bir kültürel miras olarak aktarıldığı ve topluluk üyelerinin ihtiyaçlarını bu mirasla sürdürdükleri için, bölgede göçerliğin uzun ömürlü olduğu ortaya çıkmaktadır.

Yukarıda dile getirilen sosyolojik tespitlerden hareketle, Doğu Anadolu Bölgesi'ndeki göçerlerin, bu özellikleri ön plana çıkan, özgün bir toplumsal yap1 örneği ortaya koydukları görülmektedir. Diğer yapılarda olduğu gibi, göçer toplum yapısında da kalıplaşmış sosyal ilişki biçimleri, gruplar, sosyal tabakalar ve birbiriyle fonksiyonel bağıntı içinde olan çeşitli kurumların olduğu anlaşılmaktadır.

Aşiret sistemi, birey-doğa ilişkisi, toplumu bireye tercih eden anlayışı gibi temel prensiplerle asılarca varlığını sürdüren göçer toplum yapısının, geçen asrın ikinci yarısından itibaren temel prensiplerini sorgulayan değişim talepleriyle karşılaştığı anlaşılmaktadır. Bu değişim talepleri ve sonuçları, bölgedeki göçer toplulukların, kendi kendilerine yeten toplumsal yapılarının statik olmadığını; Türkiye'de ve Dünya'da, meydana gelen ekonomik, teknolojik, sosyal, siyasal ve kültürel değişmelerden etkilendiğini (Beşikçi, 1970: 19) ortaya koymaktadır.

\subsection{Göçer Toplum Yapısının Çözülmesi ve Çöküşü}

Genel karakterini belirleyen öğeleri ve bütünleşmesini sağlayan prensipleri bu şekilde saptanan göçer toplum yapısının, yaşadığı toplumsal çözülme ve çöküşün akla gelen ilk nedeni olarak, bölgede, 1980'lerde başlayan çatışmalar gösterilebilir. Çatışma sürecinde, güvenlik gerekçesiyle göçerlere, bazı güzergahların ve birçok bölgeye gidişlerin yasaklandığı hatırlandığında, bu neden ilk bakışta makul de gelebilir. "Merkezi yönetimler ve göçerler" alt başlığı altında verilen bilgilerden, merkezi yönetimlerin, göçer toplulukları kontrol altına almak ve denetlemek amacıyla, göçerlik faaliyetinden koparmaya ve yerleşik hayata geçirmeye yönelik çabalarının hep var olduğu, ancak istenilen sonucu vermediği anlaşılmaktadır. Bölgede göçerlerin mevcut durumu, yukarıda ele alınan kavramlar ve kuramsal tartışmalar bağlamında değerlendirildiğinde, göçer toplum yapısındaki toplumsal çözülme ve çökmenin görünen neden olarak ön plana çıkan bölgedeki çatışmalardan çok daha önce başladığı sonucuna varılmaktadır. Ancak, çatışmaların, başlamış bulunan çözülme ve çöküş sürecini hızlandıran temel faktör olduğu gerçeği de sosyolojik tahlil gerektirmeyecek kadar açıktır.

$\mathrm{Bu}$ bağlamda, yapının çözülmesine ve zamanla çökmesine neden olan ilk faktörün zorunlu askerlik olduğu ileri sürülebilir. Göçer yapıların erkek üyelerinin, yirmili yaşlarda askerlik görevi için, yapıdan ayrılmasına ve farklı yapıların çeşitli imkanlar sunduğunu öğrenmesine neden olan zorunlu askerlik sistemi, önce yarı göçer ve yaylacı göçerlerde daha sonra da gerçek göçerlerde anlam kayıplarına neden oldu. Etkisi, yüzeysel bakış ve değerlendirmelerde fark edilemeyen zorunlu askerliğin, göçer toplum yapısının çözülmesinde - bir dip dalga niteliğinde ortaya çıkan ilk faktör olduğu ileri sürülebilir. Zorunlu askerlikle birlikte; bir aşirete, geniş bir aileye mensup olmak, aileye ve yaşlılara saygıyı her şeyin üstünde tutmak, sayısı en fazla olan koyun sürüsüne sahip olmak, sürü ve doğayla baş başa kalarak zaman geçirmek, kuşaktan kuşağa aktarılan yöntemlerle göçerlik faaliyetinden elde edilen ürünleri işlemek ve ailenin ihtiyaçlarını karşılayacak 
şekilde değerlendirmek gibi bir göçer için hayatın anlamını ve amacını belirleyen önceliklere çeşitli alternatifler sunduğu görülmektedir.

Göçer toplum yapısının çözülmesinde ve çökmesinde dolaylı etkenler olarak işlev gören zorunlu askerlikle birlikte etkili olan diğer bir faktör de kentlere göçtür. Askerlik dönüşü, bazı üyelerin kentlere birkaç aylığına, daha sonra iç ve dış göçe katılarak uzun süreler için çalışmaya gitmeleri ve zamanla ya gittikleri yerde evlenmeleri ya da eşlerini geldikleri yapıdan seçip götürmeleri ve nihayetinde yeni evlenecek çiftlerin mevcut yapıda, geniş aile içinde yaşamlarını sürdürmek yerine şehirde çekirdek aile biçiminde yaşamayı tercih etmeleri, buna bağlı olarak çocuklarını okutmak istemeleri; mesaisi, emekliliği, sağlık güvencesi olan kentlerdeki işleri seçmeleri yapının dağılmasına neden olan faktörlerin başında gelmektedir. Göçer bireylere, kent ortamında ulaşılabilen ve bireyin refahını ön plana çıkaran bu imkanların, göçer toplum yapısında ailenin çıkarlarını bireyin refahına ve çıkarlarına tercih eden bir toplumsal yapıdan daha cazip geldiği anlaşılmaktadır. Sonuç olarak bu değişiklikler, yapının bütünleşmesini ve sürekliliğini sağlayan ortak "anlamların" yeni üyeler için kaybolmasıyla sonuçlanmıştır. Kentleşme ${ }^{3}$ sürecine katılan yeni üyelerini kaybeden göçer toplum yapısı, tarihte sorunsuz bir şekilde toplumsal çöküş yaşayan yapılar içinde yerini almıştır.

Göçer toplum yapısı örneği, toplumsal yapılarda meydana gelen çözülme ve çöküşün daha çok dış faktörlerin etkisiyle gerçekleştiği ortaya koymaktadır. Geleneksel dönemde, dış faktörlerin, daha çok baskı ve şiddet uygulamak şeklinde gerçekleştiği anlaşılmaktadır. Yaşadığımız çağda ise, bu faktörlerin, çözülme ve çöküş yaşayan topluluklara, mevcut "yaşam biçimlerinin altı oyularak ve seçimini kendilerinin yapmadığı yeni" (Haviland, vd., 2008: 739) anlamlar, değerler, normlar ve yönetim sistemleri dayatmak biçiminde ortaya çıktığı görülmektedir.

\section{SONUÇ}

Toplumsal çöküş, gerçek anlamda bütünleşmiş mikro düzeyde bir yap1 olan göçer toplum yapısı örneğinde ele alındı. Bu örnekten hareketle, bir yapının nasıl bütünleştiği ve hangi nitelikteki faktörlerin etkisiyle çöktüğü açıklanmaya çalışıldı.

Çözülme ve çöküş, tam olarak bütünleşmiş küçük toplumsal gruplar için geçerlidir. $\mathrm{Bu}$ çerçevede göçerlerin, bütünleşmiş veya birleşmiş toplumsal gruplar olduklarından hareketle toplumsal çözülmenin de bu yapılar için geçerli olduğu söylenebilir. Diğer bir ifade ile bu grupların, aynı zamanda, birer küçük boy toplumsal yapı örnekleri oldukları ve yaşadıklarının, toplumsal çözülme ve çöküş olarak kabul edilebileceği saptaması yapılmıştır.

Göçer topluluklarda, "yapının ikili karakteri” paradoksuyla ifade edilen birey-yapı ikileminde, yapının birey karşısında belirleyici bir konuma sahip olduğu bu çalışmada da elde edilen bir tespittir. Türkiye'nin Doğu Anadolu Bölgesi'nde, 1990'lara kadar varlığını sürdüren göçer toplum yapısını belirleyen faktörün, bölgenin doğal koşullarının sonucu olan coğrafi potansiyeli olduğu, bundan dolayı bu yapıda başlıca geçim kaynağının hayvancılık, yaygın olan sosyolojik yapının ise aşiret sistemi olduğu söylenebilir.

Geleneksel dönemde, göçer toplum yapılarında toplumsal bütünleşmenin en üst düzeyde sağlandığı ve bu yapının üyeleri için geleneksel köy ve kentlerin bir çekim merkezi olmadıkları anlaşılmaktadır. Merkezi yönetimlerin bütün baskı ve zorlamalarına rağmen göçerlerin yerleşik hayata geçmeyi reddettikleri bir gerçektir.

\footnotetext{
3 Türkiye'de, göçerlerin yaşamında değişimi belirleyen başlıca faktörlerin başında kırdan kente göç gelmektedir. Türkiye'de, kentlerde yaşayan nüfus, 1927 'de, \%24.2, 1950'de \%25, 1960'ta \%31.9 iken, bu oran 1990'larda \%53'e, 2000 'de \%64.90'a, 2010 yılında ise \%76.26'ya yükseldi. Bu rakamlar, şehirlerde yaşayan nüfusun artış oranında devamlı ve istikrarlı bir yükselmenin olduğunu ve buna karşılık kır nüfusunun azaldığını göstermektedir. (TÜíK (Başbakanlık Türkiye İstatistik Kurumu), (2011), “Türkiye'de Sayım Yıllarına Göre Nüfus”, http://www.tuik.gov.tr/PreIstatistik Tablo.do?istab id=202, İnd. Tarihi: 10.06 .2013 ).
} 


\section{F.Ü. Sosyal Bilimler Dergisi 2016-26/1}

$\mathrm{Bu}$ çalışmada da, değişimin evrensel ve sürekli olduğu, toplumsal yapıların statik olmadığı, yapıyı oluşturan farklı öğelerin karşılıklı etkileşiminin değişimin temel dinamiklerinden biri olduğu prensipleri, göçer yapıları bağlamında bir kez daha doğrulandığı sonucuna varılmıştır. Modernleşme ve sanayileşmeyle, önce geleneksel kent yapılarının değiştiği ve bu değişim dalgasından sırasıyla köy ve göçer yapılarının etkilendiği tespit edilmiştir. Yapılar arasındaki etkileşimin artarak devam ettiği bu süreçte, modern kentlerde yaşamın, göçer yapıların genç üyelerine alternatif olarak sunulduğu, idealize edildiği ve kentlerin çekim merkezine dönüştürüldüğü saptanmıştır.

Günümüzde, bölgenin coğrafi potansiyelinin kaynaklık ettiği bir ekonomik faaliyet olarak az sayıda aile tarafından sürdürülen göçebeliğin niteliği, amacı, araçları ve buna bağlı olarak şekillenen toplumsal yapının sosyolojik nitelikleri büyük oranda değişmiştir. Artık göçebelik; aşirete bağlılığı ön planda tutan bir topluluk faaliyeti olmaktan çok, üyeleri çeşitli kademelerde eğitime sahip, sadece ailenin ihtiyaçları için değil, aynı zamanda piyasa için de ekonomik faaliyette bulunan az sayıda ailenin tercihi olarak sürdürülmektedir. Bu tespitler, Türkiye'de göçer toplum yapısının, dış faktörlerin bu yapının yeni üyelerini etkilemesiyle, çatışmasız çöken bir toplumsal yap1 olduğunu göstermektedir.

Göçer toplum yapısının yaşadığı değişin örneğinde, bir toplumsal yapının çözülme sürecinde, önce; toplumun üyeleri nezdinde kişi, ilişki kalıbı, yürütülen faaliyetler ve doğal olana yüklenen "anlam"ın zayıfladığı, daha sonra, bunu değerlerin ve normların etkilerinin zayıflamasını izlediği, bunun da zamanla "anlam kaybına" dönüşmesiyle toplumsal çöküşe neden olduğu sonucuna ulaşılmaktadır.

Göçerlerde toplumsal yapı üzerine yapılan bu kuramsal araştırmada, göçer toplum yapısının çatışmasız bir şekilde çöktüğü sonucuna varılması, başka toplumsal yapıların da çatışmasız bir biçimde çökertilebileceğini göstermektedir. Teknolojinin baş döndürücü bir hızla geliştiği, hayatın her alanını ve farklı düzeylerde de olsa tüm bireyleri etkilediği günümüz toplumlarında, subliminal gibi tekniklerle iletişim araçları kullanılarak bireylerin bilinçaltını şekillendiren çeşitli mesajlar verilmektedir. Böylece, bireylerin kendi toplumlarına özgü, içselleştirdikleri değerlerde "anlam kaybı" meydana getirilmekte ve yeni değerleri benimsemeye hazırlanmaktadır. Bu yöntemin; her faaliyetin gelişen ulaşım ve iletişim araçlarıyla küreselleştiği günümüz toplumlarında ve bireyin, bireye ait olanın ve bireyselleşmenin gün geçtikçe artarak etkili olacağı varsayılan gelecekte, bask1 ve şiddet kullanılarak bir toplumsal yapıyı çökertmekten daha işlevsel olduğunun anlaşılacağı ve daha sık kullanılacağı ön görülmektedir.

\section{KAYNAKÇA}

Agger, Ben (2011), Sanal Benlik, çev. Hacıoğlu, Volkan, Babil Yayınları, İstanbul

Akşit, Bahattin (2012), "Türkiye'de Modernleşmelerin ve Modernliklerin Kavramlaştırılması: M. B. Kıray'ın Araştırma Programından Yola Çıkan Bir Kuramlaştırma Denemesi”, Değişmenin ve Geçiş Toplumunun Sosyoloğu: Mübeccel B. Kıray, Y. Hazırlayan, Sezgin Tüzün, Bağlam Yayınları, İstanbul. Ankara.

Alagöz, Celal Arif (1938), Anadolu'da Yaylacılık, Cumhuriyet Halk Partisi Yayını Ankara Halkevi,

Giddens, Anthony (2000), Sosyoloji, Yayına Hazırlayan: H. Özel ve C. Güzel, Ayraç Yayınları, Ankara.

Bal, Hüseyin (1997), Alevi-Bektaşi Sosyolojisi, Ant Yayınları, İstanbul.

Beşikçi, İsmail (1968), Doğu Anadolu'daki Göçebe Kürt Aşiretlerinde Toplumsal Değişme (Geçiş Halindeki Toplumlar), Erzurum.

Beşikçi, İsmail (1970), Doğu Anadolu'nun Düzeni (Sosyo-ekonomik ve Etnik Temeller), e Yayınları, Ankara.

BOA/Başbakanlık Osmanlı Arşivi, Y.PRK. BŞK.26/85,27 Z 1309 (23 Temmuz1982).

Burkay, Kemal (1992), Geçmişten Bugüne Kürtler ve Kürdistan, Deng Yayınları, İstanbul. 
Göçerlerde Toplumsal Yapı ve Çöküs Üzerine Kuramsal...

Cole, Stephan (1999), Sosyolojik Düşünme Yöntemi Sosyoloji Bilimine Giriş, çev. B. Demirkol, Vadi Yayınları, Ankara.

Çakır, Sabri (1989), "Doğu Anadolu Göçerlerinin Sosyo-Ekonomik Sorunları." Fırat Üniversitesi Sosyal Bilimler Dergisi no. 2, s. 41-57.

Dizadji, Ali Mahmoudi (1973), Deşt-i - Mişan Bölgesinde Göçebe Hayat, İstanbul Üniversitesi Edebiyat Fakültesi, Beşeri ve İktisadi Coğrafya Kürsüsü Doktora Tezi’nin yayınlanan Göçebe Hayat konusunu içine alan bölümü, Mayataş Matbaacıllk ve Neşriyat, İstanbul.

Dönmezer, Sulhi (1982), Sosyoloji, Savaş Yayınları, Ankara.

Emecan, Feridun (2000), "Batı Anadolu'da Yörükler", Anadolu'da ve Rumeli'de Yörükler ve Türkmenler Sempozyumu Bildirileri, Ankara.

Emiroğlu ve Aydın (Ed.) ( 2003), Antropoloji Sözlüğü, Bilim ve Sanat Yayınları, Ankara.

Ercan, Fuat (2011), Kırsal Yapıda Toplumsal Değişme, Sosyal Araştırmalar Vakfi Yayınları, İstanbul.

Eriksen, Thomas Hylland (2009), Küçük Yerler Derin Mevzular Sosyal ve Kültürel antropolojiye Giriş, çev. Fahriye Adsay, Avesta Yayınları, İstanbul.

Erinç, Sırrı (1953), Doğu Anadolu Coğrafyası, İstanbul Üniversitesi Yayınları, İstanbul.

Erkilet, Alev (2013), Toplumsal Yapı ve Değiş̧me Kuramları, Hece Yayınları, Ankara.

IOM (Göç Terimleri Sözlüğü) (2009), Uluslararası Göç Hukuku, Uluslararası Göç Örgütü. Ankara.

Gökçe, Birsen (2004), Türkiye'nin Toplumsal Yapısı ve Toplumsal Kurumları, Savaş Yayınları,

Hançerlioğlu, Orham (1986), Toplumbilim Sözlüğü, Remzi Kitabevi, İstanbul.

Havıland vd., William A. (2008), Kültürel Antropoloji, çev. İ. Deniz Erguvan Sarıŏlu, Kaknüs Yayınları, İstanbul.

İbn Haldun (2011), Mukaddime, 1. Cilt, Haz. Süleyman Uludağ, Dergah Yayınları, İstanbul.

Khazanov, Anatoly M. (1984), Nomads and the Outside World, translated by Julia Crookenden ; with a foreword by Ernest Gellner, Madison: The University of Wisconsin Press.

Kıray, Mübeccel B. (1964), Ereğli: Ağır Sanayiden Önce Bir Sahil Kasabası, Başbakanlık D. P. Teşkilatı Yayınları, Ankara.

Kongar, Emre (2012a), Türk Toplumbilimcileri, Remzi Kitapevi, İstanbul.

Kongar, Emre (2012b), Toplumsal Değişme Kuramları ve Türkiye Gerçeği, Remzi Kitapevi, İstanbul.

Nirun, Nihat (1991), Sistematik Sosyoloji Yönünden Sosyal Dinamik Bünye Analizi, Atatürk Kültür Merkezi Yayınları, Ankara

Okumuş, Ejder (2007), Toplumsal Çöküş Teorileri, İnsan Yayınları, İstanbul.

Ozankaya, Özer. (1999). Toplumbilim, Cem Yayınevi, İstanbul.

Sorokin, A. Pitirim, (1972), Bir Bunalım Çağında Toplum Felsefeleri, çev. Mete Tunçay, Bilgi Yayınevi, Ankara.

Slattery, Martin (2007), Sosyolojide Temel Fikirler, haz. Tatlıcan ve Demiriz, Sentez Yayıncıllk, Bursa Ankara.

Smith, Anthony D. (1996), Toplumsal Değişme Anlayışı, Çev. Ülgen Oskay, Gündoğan Yayınları,

Spengler, Oswald (1997), Batının Çöküşü, Çev., Giovanni Scognamillo - Nyray Sengelli,Dergah Yayınları, İstanbul.

Stowasser, Barbara (1984), "İbn Khaldun'un Tarih Felsefesi: Devletlerin ve Uygarlıkların Yükselişi ve Çöküşü", çev. N. Abadan-Unat, Ankara Üniversitesi Siyasal Bilgiler Fakültesi Dergisi, cilt: 39, no: 1-4, y1l: 1984. 


\section{F.Ü. Sosyal Bilimler Dergisi 2016-26/1}

İstanbul.

Taşdelen, Hacı Musa (1997), Göçerlerin Şehirleşmesi, (Beritan Aşireti Örneği), Turan Yayınları,

Tezcan, Mahmut (1969), "Memleketimizde Köy Yaşantısının Bazı Toplumsal Sorunları ve Çözüm Yolları", Ankara Üniversitesi Eğitim Bilimleri Fakültesi Dergisi, Cilt: 2, Sayı: 1.

Thevenin, Michaël (2011), Kurdish Transhumance: Pastoral practices in South-east Turkey", http://www.pastoralismjournal.com/content/1/1/23.

Toynbee, Arnold (1978), Tarih Bilinci, Cilt 1, Çev. Murat Belge, Bateş Yayınları, İstanbul.

Tunçdilek, Necdet (1967), Türkiye İskan Coğrafyası - Kır İskanı, İstanbul Üniv. Edebiyat Fak. Yay. No. 1283, Coğrafya Enst. Yayınları, İstanbul.

Tunçdilek, Necdet (1978), Türkiye'nin Kır Potansiyeli ve sorunları, İstanbul Üniversitesi Coğrafya Enstitüsü, İstanbul Üniversitesi Yayınları.İstanbul.

TÜIK (Başbakanlık Türkiye İstatistik Kurumu), (2011), “Türkiye'de Sayım Yıllarına Göre Nüfus”, http://www.tuik.gov.tr/PreIstatistikTablo.do?istab_id=202, İnd. Tarihi: 10.06.2013).

Türkçe Sözlik (1998), Haz. İ. Parlatır, N. Gözaydın, H. Zülfikar, B. T. Aksu, s. Türkmen ve Yılmaz, Türk Dil Kurumu Yayınları, Ankara.

Türkkahraman, Mimar ve Tutar, Hüseyin (2009), "Sosyal Değişme, Bütünleşme ve Çözülme Bağlamında Toplumda Farklı Kültür ve Anlayışların Yeri ve Önemi”, Alanya İşletme Fakültesi Dergisi, 1 (1): 17-32, http://alanyadergi.akdeniz.edu.tr/_dinamik/164/17.pdf

Yalçın, B. C., (1986), Sheep and Goats in Turkey, FOOD AND AGRICULTURE ORGANIZATION OF UNITED NATIONS, ROME, http://www.fao.org/3/a-ah224e.pdf

Yalçın-Heckmann, Lale (1993), “Aşiretli Kadın: Göçer ve Yarı-Göçer Toplumlarda Cinsiyet Rolleri ve Kadın Stratejileri”, Kadın Bakış Açısından Kadınlar, Yayına Hazırlayan Şirin Tekeli, İletişim Yayınları, İstanbul.

Yazıcı, Mehmet (2011), Alevilik / Alevi Deyişlerinin ve Gülbanglarının Sosyolojik Analizi, Çıra Yayınları. İstanbul.

Yazıcı, Mehmet (2013a), "Yaşayan Tanıkların Yaşanmışlıkları Ișı̆ı̆ında Geleneksel Kürt Aile Yapısı ve Aile İçi İlişkiler", Kimlik, Kültür ve Değişim Sürecinde Osmanlı'dan Günümüze Kürtler Uluslararası Sempozyumu (06-08 Eylül 2012), Bingöl Üniversitesi Yayınları, Bingöl.

Yazıcı, Mehmet (2013b), "Toplumsal Değişim ve Sosyal Değerler", Turkish Studies - International Periodical For The Languages, Literature and History of Turkish or Turkic Volume 8/8 Summer.

Yazıcı, Mehmet (2014), "Değerler ve Toplumsal Yapıda Sosyal Değerlerin Yeri”, Firat Üniversitesi Sosyal Bilimler Dergisi, Cilt: 24, Sayı: 1, Sayfa: 209-223,

Yılmaz, Anıl ve Telci, Cahit (2010), "Türk Kültür Terminolojisinde Göç Kavramı Üzerine”, Modern Türklük Araştırmaları Dergisi, cilt 7, Sayı 2. 